\title{
Stimulation of mGluR5 in the Accumbens Shell Promotes Cocaine Seeking by Activating PKC Gamma
}

\author{
Heath D. Schmidt, Rachel L. Schassburger, Leonardo A. Guercio, and R. Christopher Pierce \\ Center for Neurobiology and Behavior, Department of Psychiatry, Perelman School of Medicine at the University of Pennsylvania, Philadelphia, \\ Pennsylvania 19104
}

Recent studies indicate a critical role for metabotropic glutamate receptor 5 (mGluR5) in the reinstatement of cocaine seeking. However, the signal transduction pathways through which mGluR5s regulate cocaine seeking have not been identified. Here, we show that intraaccumbens shell administration of an mGluR5 (9.0 $\mu \mathrm{M}$ MPEP), but not mGluR1 (50.0 $\mu \mathrm{M}$ YM 298198), antagonist before a priming injection of cocaine $(10 \mathrm{mg} / \mathrm{kg})$ attenuated the reinstatement of drug seeking in rats. Consistent with these results, intra-shell microinjection of the mGluR1/5 agonist DHPG $(250 \mu \mathrm{M})$ promoted cocaine seeking. Intra-shell administration of a phospholipase C (PLC) inhibitor (40.0 $\mu \mathrm{M}$ U73122) or a protein kinase C (PKC) inhibitor (10.0 $\mu \mathrm{M}$ Ro 31-8220 or $30.0 \mu \mathrm{m}$ chelerythrine chloride) attenuated cocaine seeking. Pharmacological inhibition of PKC in the shell also blocked intra-shell DHPG-induced reinstatement of cocaine seeking. In addition, cocaine priming-induced reinstatement of drug seeking was associated with increased phosphorylation of PKC $\gamma$, but not PKC $\alpha$ or PKC $\beta$ II, in the shell. Cocaine seeking previously was linked to increased phosphorylation of GluA2 at Ser880, a PKC phosphorylation site, which promotes the endocytosis of GluA2-containing AMPA receptors via interactions with Protein Associated with C Kinase (PICK1). The present results indicated that inhibition of PICK1 (100 $\mu \mathrm{M}$ FSC-231) in the shell attenuated cocaine seeking. There were no effects of any drug treatment in the shell on sucrose seeking. Together, these findings indicate that accumbens shell mGluR5 activation promotes cocaine seeking, in part, through activation of PLC and PKC $\gamma$. Moreover, the endocytosis of shell GluA2-containing AMPARs during cocaine seeking may depend on interactions with PKC $\gamma$ and PICK1.

\section{Introduction}

A growing body of evidence indicates that metabotropic glutamate receptor 5 (mGluR5) plays a significant role in cocaineinduced neuroadaptations and behavioral responses. Mutant mice lacking mGluR5s are insensitive to the locomotor stimulant properties of cocaine and do not self-administer this psychostimulant (Chiamulera et al., 2001). Consistent with these findings, subsequent studies demonstrated that systemic administration of the mGluR5 receptor antagonist, MPEP, decreased cocaine self-administration (Kenny et al., 2003, 2005; Lee et al., 2005; Platt et al., 2008) and attenuated the ability of a priming injection of cocaine (Lee et al., 2005) or cocaine-associated cues (Bäckström and Hyytiä, 2006) to reinstate cocaine seeking. Furthermore, administration of MPEP directly into the nucleus accumbens shell attenuated cocaine priming-induced reinstatement of drug seeking, an animal model of relapse (Kumaresan et al., 2009). Together, these findings indicate that activation of mGluR5s, specif-

\footnotetext{
Received May 29, 2013; revised July 1, 2013; accepted July 26, 2013.

Author contributions: H.D.S. and R.C.P. designed research; H.D.S., R.L.S., and L.A.G. performed research; H.D.S., R.L.S., L.A.G., and R.C.P. analyzed data; H.D.S. and R.C.P. wrote the paper.

This work was supported by the following grants from the National Institutes of Health: K01 DA030445 (H.D.S.), DA022339 (R.C.P.), DA033641 (R.C.P.), and K02 DA18678 (R.C.P.). We would also like to thank Blake Kimmey, Adrian Arreola, and David Reiner for their technical assistance.

The authors declare no competing financial interests.

Correspondence should be addressed to Dr. Heath D. Schmidt, Center for Neurobiology and Behavior, Perelman

School of Medicine at the University of Pennsylvania, 125 South 31st Street, Philadelphia, PA 19104. E-mail: hschmidt@mail.med.upenn.edu.

DOI:10.1523/JNEUROSCI.2284-13.2013

Copyright $\odot 2013$ the authors $\quad 0270-6474 / 13 / 3314160-10 \$ 15.00 / 0$
}

ically in the accumbens shell, may promote the reinstatement of cocaine seeking.

mGluR5s, along with mGluR1s, are classified as group I mGluRs, which are expressed predominantly on postsynaptic membranes (Rouse et al., 2000; Muly et al., 2003) throughout the brain, including the nucleus accumbens (Shigemoto et al., 1993; Testa et al., 1995). Stimulation of group I mGluRs activates phospholipase C (PLC), which, in turn, catalyzes the hydrolysis of phosphatidylinositol 4,5-bisphosphate $\left(\mathrm{PIP}_{2}\right)$ generating diacylglycerol (DAG) and inositol triphosphate $\left(\mathrm{IP}_{3}\right)$. Increasing concentrations of DAG following PLC activation results in activation of protein kinase C (PKC) (Conn and Pin, 1997). Potential roles for PLC, DAG, and/or $\mathrm{IP}_{3}$ in the behavioral response to cocaine have not been examined. However, previous studies have demonstrated a role for PKC in psychostimulant-mediated behaviors. For example, repeated cocaine administration increases the phosphorylation of some, but not all, isoforms of PKC in the nucleus accumbens (Steketee et al., 1998). Furthermore, PKC mRNA expression is increased in limbic areas, including the accumbens, following $5 \mathrm{~d}$ of withdrawal from self-administered cocaine (Thomas and Everitt, 2001). Administration of a PKC inhibitor directly into the nucleus accumbens attenuated amphetamine-mediated conditioned place preference (CPP) (Aujla and Beninger, 2003), and systemic administration of a PKC inhibitor attenuated cocaine-induced CPP (Cervo et al., 1997). Similarly, administration of a PKC inhibitor directly into the accumbens blocked the expression of cocaine-induced behavioral sensitization (Pierce et al., 1998). While these results 
show that PKC plays a role in some cocaine-mediated behaviors, no studies have examined PKC activation during the reinstatement of cocaine seeking or characterized the signaling pathways through which type $1 \mathrm{mGluRs}$ promote cocaine seeking.

The present study had three mail goals: (1) to assess the roles of mGluR1, mGluR5, PLC, and PKC in the nucleus accumbens shell in the reinstatement of cocaine-seeking behavior; (2) to determine the effect of cocaine priming-induced reinstatement on the expression of native and phosphorylated PKC isoforms in the accumbens shell; and (3) to evaluate the role of PKC in mediating the effects of mGluR1/5 agonist-induced reinstatement of cocaine seeking. Our results indicate that stimulation of accumbens shell mGluR5s, but not mGluR1s, promotes cocaine seeking, in part, through activation of PKC $\gamma$.

\section{Materials and Methods}

Animals and housing. Male Sprague Dawley rats (Rattus norvegicus) weighing 250-300 g were obtained from Taconic Laboratories. Animals were individually housed with food and water available ad libitum in their home cage. A $12 / 12 \mathrm{~h}$ light/dark cycle was used with the lights on at 7:00 A.M. All experimental procedures were performed during the light cycle. The experimental protocols were all consistent with the guidelines issued by the U.S. National Institutes of Health and were approved by the University of Pennsylvania's Institutional Animal Care and Use Committee.

Surgery. Before surgery, rats were anesthetized with $80 \mathrm{mg} / \mathrm{kg}$ ketamine and $12 \mathrm{mg} / \mathrm{kg}$ xylazine (Sigma-Aldrich). An indwelling catheter (CamCath) was inserted into the right jugular vein and sutured in place. The catheter was routed to a mesh backmount platform that was implanted subcutaneously dorsal to the shoulder blades. Catheters were flushed daily with $0.3 \mathrm{ml}$ of antibiotic (Timentin, $0.93 \mathrm{mg} / \mathrm{ml}$ ) dissolved in heparinized saline and sealed with plastic obturators when not in use.

After catheter insertion, some rats were then immediately mounted in a stereotaxic apparatus (Kopf Instruments). Guide cannulas (14 mm, 24 gauge) for microinjections were implanted bilaterally $2 \mathrm{~mm}$ dorsal to the medial nucleus accumbens shell. Guide cannulas were cemented in place by affixing dental acrylic to stainless steel screws secured in the skull. The coordinates for the ventral ends of the guide cannulas, relative to bregma according to the atlas of Paxinos and Watson (1997), were as follows: $+1.0 \mathrm{~mm} \mathrm{~A} / \mathrm{P}, \pm 1.0 \mathrm{~mm} \mathrm{M} / \mathrm{L}$, and $-5.0 \mathrm{~mm} \mathrm{D} / \mathrm{V}$. An obturator $(14 \mathrm{~mm}$, 33 gauge) was inserted into each guide cannula to prevent occlusion.

Cocaine self-administration and extinction. After surgery, rats were allowed $7 \mathrm{~d}$ to recover before behavioral testing commenced. Initially, rats were placed in operant chambers and allowed to lever-press for intravenous infusions of cocaine $(0.25 \mathrm{mg}$ cocaine $/ 59 \mu \mathrm{l}$ saline, infused over a $5 \mathrm{~s}$ period) on a fixed-ratio 1 (FR1) schedule of reinforcement. Each operant session began with the intravenous administration of $59 \mu \mathrm{l}$ of cocaine $(0.25 \mathrm{mg})$ to fill the catheter. Rats were allowed to self-administer a maximum of 30 injections per $120 \mathrm{~min}$ operant session. Once an animal achieved at least 20 infusions of cocaine in a single daily operant session under the FR1 schedule, the subject was switched to a fixed-ratio 5 (FR5) schedule of reinforcement. The maximum number of injections was again limited to 30 per daily self-administration session under the FR5 schedule. For both FR1 and FR5 schedules, a 20 s time-out period followed each cocaine infusion, during which time active lever responses were tabulated but had no scheduled consequences. Responses made on the inactive lever, which had no scheduled consequences, were also recorded during both the FR1 and FR5 training sessions.

Following $21 \mathrm{~d}$ of daily cocaine self-administration sessions, drugseeking behavior was extinguished by replacing the cocaine with $0.9 \%$ saline. Daily extinction sessions continued until responding on the active lever was $<15 \%$ of the response rate maintained by cocaine selfadministration under the FR5 schedule of reinforcement. Typically, it took $\sim 7 \mathrm{~d}$ for rats to meet this criterion. The total active lever responses (mean \pm SEM) on the last day of extinction for all animals used in the cocaine reinstatement experiments was $15.87 \pm 0.60$.

Reinstatement of cocaine seeking. Once cocaine self-administration was extinguished, animals entered the reinstatement phase of the experi- ment. During reinstatement test sessions, satisfaction of the response requirement (i.e., five presses on the active lever) resulted in saline rather than cocaine infusion. Using a between-sessions reinstatement paradigm, each reinstatement test session was followed by extinction sessions until responding was again $<15 \%$ of the response rate maintained by cocaine self-administration. Generally, 1-2 d of extinction were necessary to reach extinction criterion between reinstatement test sessions. The FR5 schedule was used throughout the extinction and reinstatement phases of these experiments.

The effect of intra-accumbal shell pretreatment with the mGluR1 antagonist YM 298198, the mGluR5 antagonist MPEP, the PLC inhibitor U73122, the PKC inhibitors Ro 31-8220 and chelerythrine chloride, and the protein-interacting kinase 1 (PICK1) inhibitor FSC-231 on cocaine priming-induced reinstatement of drug seeking was assessed. YM 298198 (5.0 and $50.0 \mu \mathrm{M} / 0.5 \mu \mathrm{l}$ ), MPEP $(9.0 \mu \mathrm{M} / 0.5 \mu \mathrm{l})$, U73122 (4.0 and 40.0 $\mu \mathrm{M} / 0.5 \mu \mathrm{l}$ ), Ro $31-8220$ (1.0 and $10.0 \mu \mathrm{M} / 0.5 \mu \mathrm{l}$ ), chelerythrine chloride (3.0 and $30.0 \mu \mathrm{M} / 0.5 \mu \mathrm{l}), \mathrm{FSC}-231(10.0$ and $100 \mu \mathrm{M} / 0.5 \mu \mathrm{l})$, and respective vehicles were microinjected into the accumbens shell $10 \mathrm{~min}$ before a priming injection of cocaine $(10 \mathrm{mg} / \mathrm{kg}$, i.p.).

The ability of the mGluR1/5 agonist 3,5-DHPG to reinstate cocaine seeking was assessed in a separate experiment. DHPG (25.0 and 250 $\mu \mathrm{M} / 0.5 \mu \mathrm{l}$ ) was microinjected bilaterally into the accumbens shell immediately before the reinstatement test session. To determine whether PKC mediates DHPG-induced reinstatement of cocaine seeking, Ro 31-8220 $(10.0 \mu \mathrm{M} / 0.5 \mu \mathrm{l})$ was microinjected into the shell $10 \mathrm{~min}$ before intrashell infusions of DHPG $(250 \mu \mathrm{m} / 0.5 \mu \mathrm{l})$.

Microinjection procedures. The obturators were removed from the guide cannulas and 33 gauge, $16 \mathrm{~mm}$ stainless steel microinjectors were inserted. Bilateral infusions were performed simultaneously over $2 \mathrm{~min}$ in a total volume of $0.5 \mu \mathrm{l}$ per hemisphere. Following infusion, microinjectors were left in place for an additional $1 \mathrm{~min}$ to allow for diffusion of the drug solution away from the tips of the microinjectors. The goal of the experimental design was to have each animal serve as its own control and receive up to four microinjections. However, we were forced to deviate from this experimental design when technical difficulties (i.e., blocked guide cannulas) made it impossible to test all doses of a compound plus vehicle in an entire cohort of subjects. In every case, however, an animal received at a minimum treatment of one drug dose and its vehicle. To control for potential rank order effects of drug and vehicle administrations, all treatments were counterbalanced across reinstatement test sessions. However, the loss of some animals from an experiment because of technical difficulties may have comprised aspects of the counterbalanced design. Therefore, all subjects that failed to receive all of the scheduled microinjections underwent a final reinstatement test session in the absence of any intracranial drug infusion to confirm that the reinstatement response to an acute priming injection of cocaine $(10 \mathrm{mg} /$ $\mathrm{kg}$, i.p.) remained robust.

Using this experimental design, the rats underwent a series of extinction and reinstatement test sessions. During such repeated extinction sessions, extinction of the ability of cocaine to induce reinstatement of drug seeking is a concern. However, we have previously shown that reinstatement of cocaine seeking persists for at least $20 \mathrm{~d}$ after the initial extinction of cocaine self-administration (Park et al., 2002; Anderson et al., 2003). In all cases, the drug and vehicle treatments were counterbalanced across reinstatement test days. Therefore, we were able to determine whether cocaine reinstatement was extinguished following repeated priming injections of cocaine using vehicle-treated controls. All subjects demonstrated stable drug seeking throughout the reinstatement phase of these experiments. This was measured with systemic priming injections of cocaine $(10 \mathrm{mg} / \mathrm{kg}$, i.p. ) at the beginning, middle, and end of the reinstatement test phase.

Reinstatement of sucrose seeking. Potential nonspecific ratesuppressing effects of intra-shell MPEP, YM 298198, U73122, Ro 31-8220, chelerythrine chloride, and FSC-231 were evaluated by assessing the influence of these compounds on the reinstatement of sucroseseeking behavior. Separate cohorts of rats were trained initially to selfadminister $45 \mathrm{mg}$ of sucrose pellets (Research Diets) on a FR1 schedule of reinforcement during daily $1 \mathrm{~h}$ operant sessions. Once animals achieved stable responding for sucrose (defined as $<20 \%$ variation in responding 
over 3 consecutive days) on the FR1 schedule of reinforcement, the response requirement was increased to an FR5 schedule of reinforcement. Animals were limited to 30 sucrose pellets within a $1 \mathrm{~h}$ operant session and were food restricted to 15-20 g of laboratory chow (Harlan Teklad) in their home cages for the duration of the experiment. Water was continuously available in the home cage.

After 2 weeks of sucrose-maintained responding on an FR5 schedule of reinforcement, rats underwent an extinction phase where lever pressing no longer resulted in sucrose delivery. Once lever responding decreased to $<15 \%$ of the maximum number of responses completed during sucrose self-administration, animals proceeded to reinstatement testing. The total active lever responses (mean \pm SEM) on the last day of extinction for all animals used in the sucrose reinstatement experiments was $22.60 \pm 0.74$. Behaviorally relevant doses of MPEP $(9.0 \mu \mathrm{M} / 0.5 \mu \mathrm{l})$, YM $298198(50.0 \mu \mathrm{M} / 0.5 \mu \mathrm{l}), \mathrm{U} 73122(40.0 \mu \mathrm{M} / 0.5 \mu \mathrm{l})$, Ro 31-8220 (10.0 $\mu \mathrm{M} / 0.5 \mu \mathrm{l})$, chelerythrine chloride $(30.0 \mu \mathrm{M} / 0.5 \mu \mathrm{l})$, and FSC-231 (100 $\mu \mathrm{M} / 0.5 \mu \mathrm{l})$ that attenuated cocaine priming-induced reinstatement of drug seeking were microinjected into the accumbens shell $10 \mathrm{~min}$ before the beginning of the reinstatement session. Using a within-subjects design, each animal served as its own control and received at most three microinjections. The experimenter remotely administered one sucrose pellet every $2 \mathrm{~min}$ for the first $10 \mathrm{~min}$ of the reinstatement session. A between-session paradigm was used so that each daily reinstatement test session was followed by an extinction session the following day until responding was again $<15 \%$ of the response rate maintained by sucrose. Rats were tested for sucrose seeking in the absence of an intracranial drug infusion at the end of the experiment to ensure that reinstatement of sucrose seeking had not been extinguished.

Verification of cannula placements. After completion of all microinjection experiments, rats were given an overdose of pentobarbital (100 mg/ $\mathrm{kg}$ ) and perfused with $0.9 \%$ saline followed by $10 \%$ formalin. Brains were removed and coronal sections $(100 \mu \mathrm{m})$ were taken at the level of the nucleus accumbens with a Vibratome. The sections were mounted on gelatin-coated slides and stained with cresyl violet. An individual blinded to behavioral responses determined cannula placements as well as excessive cannula-induced damage (defined as a cannula tract in excess of 500 $\mu \mathrm{m}$ ) or drug-induced neurotoxicity (defined as neuronal death extending beyond $100 \mu \mathrm{m}$ from the cannula tract) using light microscopy. Animals with cannula placements outside of the medial accumbens shell, excessive mechanical damage, or neurotoxicity were excluded from subsequent data analysis.

Drugs. Cocaine was obtained from the National Institute on Drug Abuse and dissolved in bacteriostatic $0.9 \%$ saline. MPEP hydrochloride (2-methyl6-(phenylethynyl)pyridine), YM 298198 hydrochloride (6-amino- $N$ cyclohexyl- $N$, 3-dimethylth-iazolo[3,2-a] benzimidazole-2-carboxamide hydrochloride), U73122 (1-[6-[[(17 $\beta$ )-3-Methoxyestra-1,3,5(10)-trien-17yl]amino]hexyl]-1 H-pyrrole-2,5-dione), Ro 31-8220 mesylate (3-[3-[2, 5-dihydro-4-(1-methyl-1 $H$-indol-3-yl)-2, 5-dioxo- $1 H$-pyrrol-3-yl]-1 $H$ indol-1-yl]propyl carbamimidothioic acid ester mesylate), chelerythrine chloride (1,2-dimethoxy-12-methyl[1,3]benzodioxolo[5,6]phenanthridinium chloride), and 3,5-DHPG (3,5-dihydroxyphenylglycine) were purchased from Tocris Bioscience. YM 298198, chelerythrine chloride, and 3,5-DHPG were dissolved in sterile $0.9 \%$ saline. MPEP, U73122, and Ro 31-8220 were dissolved in $100 \%$ DMSO to make stock solutions and then diluted in sterile $0.9 \%$ saline to required final working concentrations, resulting in final vehicle concentrations of $1 \%$ DMSO. The dose ranges for each of the aforementioned pharmacological compounds were based on the following rat intracranial microinjection experiments: MPEP (Bäckström and Hyytiä, 2007; Kumaresan et al., 2009; D'Souza and Markou, 2011), YM 298198 (Titley et al., 2010; Timmer and Steketee, 2012), U73122 (Yang and Hwang, 2007; Frye and Walf, 2008), Ro 31-8220 mesylate (Loweth et al., 2009), chelerythrine chloride (Narita et al., 2004; Li et al., 2011), 3,5-DHPG (Swanson et al., 2001; Schwendt et al., 2012). FSC 231 was a gift generously provided by Thor Thorsen (The Panum Institute, University of Copenhagen, Denmark). FSC 231 doses were based on behaviorally relevant doses used previously in the rat brain (Thorsen et al., 2010).

Cocaine self-administration and yoked saline controls for Western blotting experiments. Rats underwent catheterization as described above and were allowed to recover for $7 \mathrm{~d}$ before cocaine self-administration com- menced. Rats were randomly assigned to one of four groups (self-administration/challenge injection): cocaine/cocaine, cocaine/saline, yoked saline/cocaine, or yoked saline/saline. Within each individual experiment, rats were randomly assigned to experimental and control groups. Each rat trained to respond for contingent cocaine infusions was paired with a yoked subject that received infusions of saline. Lever pressing for the saline-yoked rats had no scheduled consequences, but these animals received the same number and temporal pattern of infusions as selfadministered by the paired cocaine-experimental rat.

Initially, cocaine-experimental rats were placed in the operant chambers and allowed to lever press for intravenous cocaine infusions $(0.25$ $\mathrm{mg}$ cocaine/59 $\mu \mathrm{l}$ saline, infusion over $5 \mathrm{~s}$ ) on a FR1 schedule of reinforcement. Once a cocaine-experimental rat achieved stable responding on the FR1 schedule, they were switched to an FR5 schedule of reinforcement. For responding on both FR1 and FR5 schedules, the maximum number of cocaine infusions was limited to 30 per daily self-administration session and a $20 \mathrm{~s}$ time-out period followed each cocaine infusion. Daily 2 h operant sessions (5-6 d/week) were conducted for a total of $21 \mathrm{~d}$. Cocaine self-administration was then extinguished as described above. After rats met their extinction criteria, one half of the cocaine self-administration rats and one half of the yoked saline controls received an acute injection of cocaine $(10 \mathrm{mg} / \mathrm{kg}$, i.p.), whereas the remaining animals received an injection of saline. All rats were then placed in the operant chambers under extinction conditions. Thirty minutes after the cocaine or saline injection, rats were removed from the operant chambers and immediately decapitated. Brains were then removed and the nucleus accumbens shell was dissected on ice. Brain tissue samples were stored at $-80^{\circ} \mathrm{C}$ until further analysis.

Western blotting. Accumbens shell tissue was homogenized with a Polytron (Brinkman Instruments) in 10 volumes of homogenization buffer, pH 7.4, consisting of 20 mm Tris, 10 mM EGTA, 2 mM EDTA, 0.25 M sucrose, $1 \mathrm{~mm}$ phenylmethylsulfonyl fluoride, and a 1:100 dilution of a protease inhibitor cocktail (Sigma-Aldrich) and a serine/threonine phosphatase inhibitor cocktail (Sigma-Aldrich). Following homogenization, samples were centrifuged at $10,000 \times g$ at $4^{\circ} \mathrm{C}$ for $10 \mathrm{~min}$. Protein content was determined with a Bio-Rad protein assay kit. For Western analysis, $20 \mu \mathrm{g}$ of protein was separated on $10 \%$ Bis-Tris gels (Invitrogen) using SDS-PAGE. Proteins were transferred to nitrocellulose membranes, which were then preblocked with PBS containing $0.1 \%$ Tween 20 and $5 \%$ bovine serum albumin for $1 \mathrm{~h}$ before overnight incubation with primary antibodies. Membranes were incubated overnight at $4^{\circ} \mathrm{C}$ with the following primary antibodies that have been used previously to examine expression of native and phosphorylated $\mathrm{PKC}$ isoforms in whole-cell tissue extracts from rat brain: anti-PKC $\alpha$ (Abcam, 1:1000) (Zhang et al., 2011), anti-PKC $\beta I I$ (Santa Cruz Biotechnology, 1:500 dilution) (Olive et al., 2005), anti-PKC $\gamma$ (Abcam, 1:1000) (Zhang et al., 2011), anti-phosphoPKC $\alpha /$ PKC $\beta$ II Thr638/641 (Cell Signaling Technology, 1:1000 dilution) (Olive et al., 2005), and anti-phospho-PKC $\gamma$ Thr674 (Abcam, 1:500) (Wilkie et al., 2007). Membranes were concurrently incubated with mouse monoclonal anti-GAPDH (Cell Signaling Technology, 1:3000) as a loading control. Primary antibody incubation was followed by three washes [10 min each with rocking, room temperature (RT)] in Tris-buffered saline containing $0.2 \%$ Tween 20 . Membranes were then incubated for $1 \mathrm{~h}$ at RT with secondary antibodies (IRDye 800 goat anti-mouse and IRDye 680 goat anti-rabbit, 1:5000) in Odyssey blocking buffer $+0.05 \%$ Tween 20 (LI-COR Biosciences). Antibody/protein complexes were visualized using the Odyssey IR imaging system (Li-Cor Biosciences). Band intensities were quantified using the Odyssey software. For data analysis, native and phosphorylated PKC bands were normalized to GAPDH and divided by the mean of the control group. The ratio of phosphorylated to native protein was then calculated.

Statistics. For the cocaine reinstatement experiments using YM 298198, U73122, Ro 31-8220, chelerythrine chloride, DHPG, or FSC-231 in the accumbens shell, the total mean active and inactive lever responses were analyzed with one-way ANOVAs. Total mean active and inactive lever responses for all sucrose reinstatement tests sessions and the following intra-shell administration of MPEP during cocaine reinstatement were analyzed with un-paired $t$ tests. Two-way mixed factor ANOVAs were used to analyze PKC isoform expression data. Pairwise comparisons 
A mGluR1 antagonist

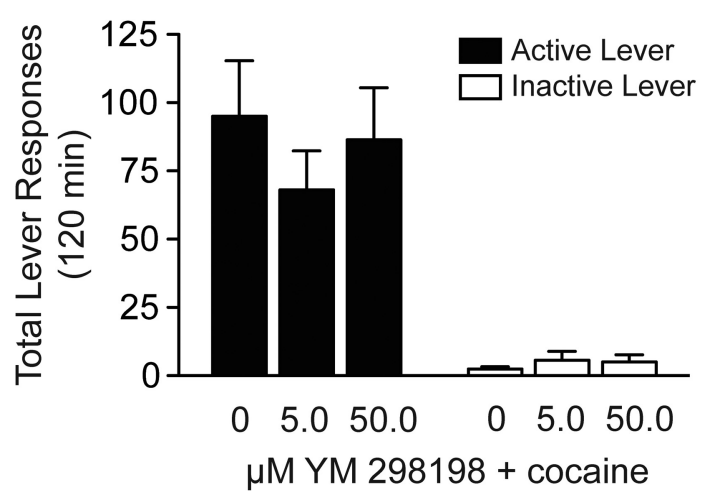

B mGluR5 antagonist

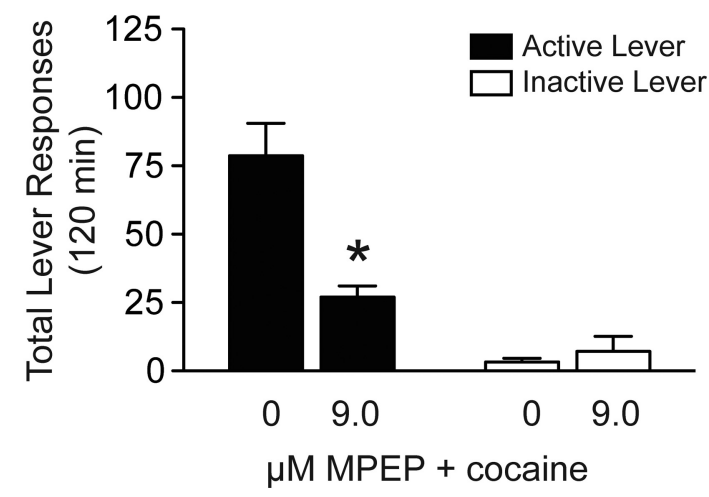

Figure 1. Administration of the mGluR5 antagonist MPEP, but not the mGluR1 antagonist YM 298198, into the accumbens shell, attenuates cocaine priming-induced reinstatement of drug seeking. $\boldsymbol{A}$, Rats were administered vehicle, 5.0 or $50.0 \mu \mathrm{M}$ YM 298198 into the accumbens shell $10 \mathrm{~min}$ before a priming injection of cocaine ( $10 \mathrm{mg} / \mathrm{kg}$, i.p.) during the reinstatement phase $(n=$ $9 /$ treatment). No significant differences in responding on the active or inactive levers (mean \pm SEM) were found between treatments. $\boldsymbol{B}$, Total number of responses (mean \pm SEM) on the active and inactive levers during the reinstatement session following intra-accumbens administration of vehicle $(n=7)$ or $9.0 \mu \mathrm{M}$ MPEP ( $n=8$ ). ${ }^{*} p<0.001$ for active lever responding between treatments (unpaired $t$ test).

were made with Tukey's HSD ( $p<0.05$ ) following one-way ANOVAs and Bonferroni correction following two-way ANOVAs $(p<0.05)$.

\section{Results}

Pharmacological inhibition of mGluR5s, but not mGluR1s, in the accumbens shell attenuated the reinstatement of cocaine seeking

Total active and inactive lever responses (mean \pm SEM) following a systemic priming injection of cocaine $(10 \mathrm{mg} / \mathrm{kg}$, i.p. $)$ in animals pretreated with microinfusions of the mGluR1 antagonist YM 298198 (vehicle, 5.0 or $50.0 \mu \mathrm{M}, n=9$ /treatment) into the accumbens shell are shown in Figure $1 A$. These data were analyzed with one-way ANOVAs, which did not reveal any significant differences between treatments on responses made on the active $\left(F_{(2,24)}=0.58, p<0.57\right)$ or inactive $\left(F_{(2,24)}=0.47, p<\right.$ $0.63)$ levers. Total lever responses (mean \pm SEM) in rats pretreated with the mGluR5 antagonist MPEP are shown in Figure 1B. In contrast to YM 298198, 9.0 $\mu \mathrm{M}$ MPEP $(n=8)$ infused directly into the accumbens shell significantly decreased total active lever responses compared with vehicle-treated controls $(n=7)$ following a systemic priming injection of cocaine $\left(t_{(13)}=\right.$ $4.342, p<0.001)$. No significant differences in responses made on the inactive lever were found between treatments $\left(t_{(13)}=0.63\right.$, $p<0.54)$.Together, these results suggest that activation of mGluR5s, but not mGluR1s, in the accumbens shell promote the reinstatement of cocaine seeking.

Microinjection of the phospholipase C inhibitor, U73122, or the protein kinase $\mathrm{C}$ inhibitors, Ro 31-8220 or chelerythrine chloride, into the accumbens shell, attenuated the reinstatement of cocaine seeking

Rats were administered $0,4.0$, or $40.0 \mu \mathrm{M} \operatorname{U} 73122$ ( $n=8 /$ treatment) into the accumbens shell before a priming injection of cocaine during the reinstatement test phase. Total lever responses (mean \pm SEM) in rats pretreated with vehicle or U73122 are shown in Figure 2. The active lever data in Figure 2 were analyzed with a one-way ANOVA, which revealed a significant main effect of treatment $\left(F_{(2,21)}=9.18, p<0.01\right)$. Subsequent pairwise analyses showed that total active lever responses were significantly different between rats pretreated with vehicle or $4.0 \mu \mathrm{M} \mathrm{U} 73122$ and those pretreated with $40.0 \mu \mathrm{M}$ U73122 (Tukey's HSD, $p<$ $0.05)$. Total inactive lever data in Figure 2 were analyzed with

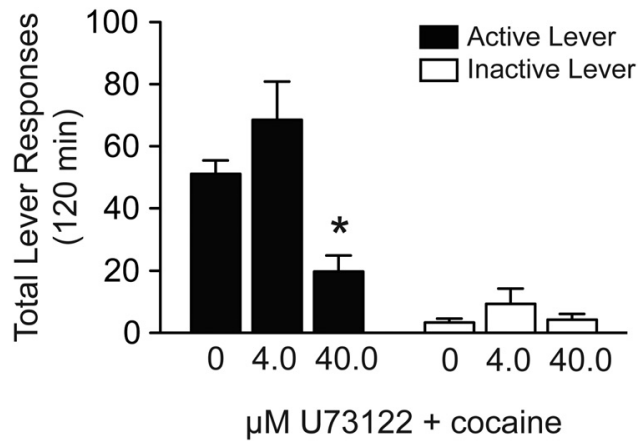

Figure 2. Administration of the phospholipase C inhibitor U73122 directly into the accumbens shell attenuates cocaine priming-induced reinstatement of drug seeking. Total active and inactive lever responses (mean \pm SEM) during the reinstatement test session following a 10 $\mathrm{mg} / \mathrm{kg}$ priming injection of cocaine in rats pretreated with intra-accumbens shell vehicle, 4.0 or $40.0 \mu \mathrm{m}$ U73122 ( $n=8 /$ treatment). ${ }^{*} p<0.05$ for active lever responding between vehicle and $4.0 \mu \mathrm{m}$ U73122 and $40.0 \mu \mathrm{m}$ U73122 (Tukey's HSD).

a one-way ANOVA. No significant differences were found on inactive lever responding between treatments $\left(F_{(2,21)}=1.07\right.$, $p<0.36)$.

Total lever responses (mean \pm SEM) following intraaccumbens shell administration of the PKC inhibitors Ro 318220 and chelerythrine chloride before a systemic priming injection of cocaine are shown in Figure 3. Total active and inactive lever responses in animals pretreated with microinfusions of Ro 31-8220 (vehicle, $n=12 ; 1.0 \mu \mathrm{M}$ Ro 31-8220, $n=11$; and 10.0 $\mu \mathrm{M}$ Ro $31-8220, n=11)$ directly into the accumbens shell are plotted in Figure $3 A$. Active lever responses were analyzed with a one-way ANOVA, which revealed a significant main effect of treatment $\left(F_{(2,31)}=10.83, p<0.001\right)$. Subsequent pairwise analyses showed significant differences in responding on the active lever between animals pretreated with vehicle or $1.0 \mu \mathrm{M}$ Ro 318220 and those treated with $10.0 \mu \mathrm{M}$ Ro 31-8220 (Tukey's HSD, $p<0.05)$. No significant effects of treatment on inactive lever responding were observed $\left(F_{(2,31)}=0.15, p<0.86\right)$. Total active and inactive lever responses in a separate cohort of animals pretreated with intra-accumbens shell infusions of chelerythrine chloride (vehicle, 3.0 and $30 \mu \mathrm{M}$ chelerythrine chloride, $n=12$ / treatment) before a priming injection of cocaine are shown in Figure 
A

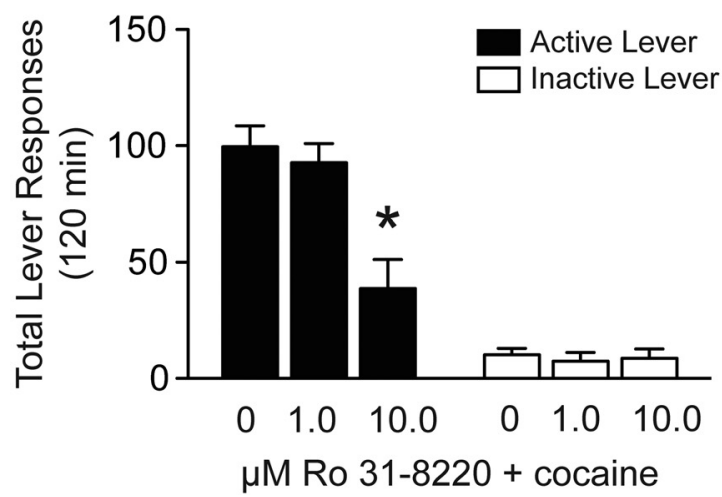

B

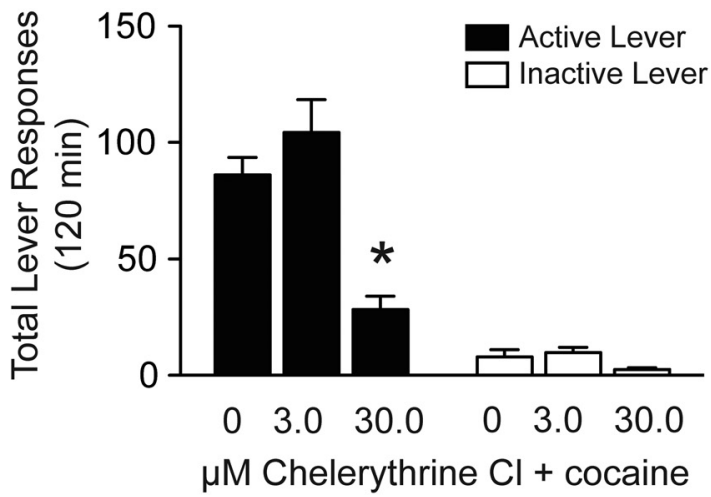

Figure 3. Microinjection of the PKC inhibitors Ro 31-8220 and chelerythrine chloride into the accumbens shell dose-dependently attenuates cocaine priming-induced reinstatement of drug seeking. $\boldsymbol{A}$, Total number of responses (mean \pm SEM) on the active and inactive levers during the reinstatement test session following a priming injection of cocaine (10 mg/kg, i.p.) in rats pretreated with vehicle $(n=12), 1.0(n=11)$ or $10.0(n=11) \mu \mathrm{m}$ Ro 31-8220 into the accumbens shell. ${ }^{*} p<0.05$ between vehicle or $1.0 \mu \mathrm{m}$ Ro $31-8220$ and $10.0 \mu \mathrm{m}$ Ro $31-8220$ with regards to active lever responses (Tukey's HSD). B, Rats were administered vehicle, 3.0 or $30.0 \mu \mathrm{m}$ chelerythrine chloride ( $n=12 /$ treatment) into the accumbens shell before a priming injection of cocaine (10 mg/kg, i.p.) during the reinstatement phase. Depicted are the total (mean \pm SEM) active and inactive lever responses during the reinstatement test sessions. The asterisk represents a significant difference in active lever responding between rats treated with vehicle or $3.0 \mu \mathrm{m}$ chelerythrine chloride and rats treated with $30.0 \mu \mathrm{m}$ chelerythrine chloride (Tukey's HSD, $p<0.05$ ). No significant differences were observed on inactive lever responding following intra-accumbens shell administration of any dose of Ro 31-8220 or chelerythrine chloride.
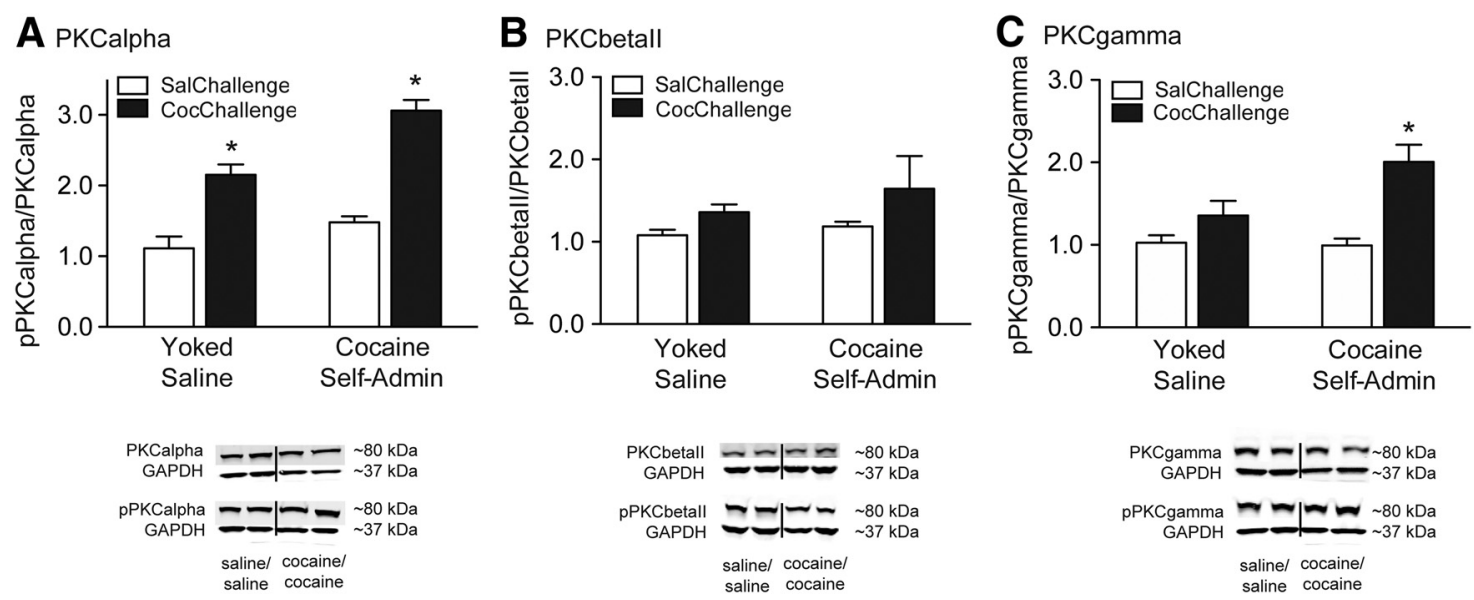

Figure 4. The reinstatement of cocaine seeking is associated with increased expression of phosphorylated PKC $\gamma$ in the nucleus accumbens shell. Representative Western blots for PKC isoforms and GAPDH (loading control) in the accumbens shell from cocaine self-administration/cocaine challenge injection and yoked saline/cocaine challenge injection treatments are shown (yoked saline/saline challenge injection and cocaine self-administration/saline challenge injection blots not shown). Fluorescent densitometric values from all Western blots were normalized to GAPDH and then plotted as the ratio of phosphorylated to native PKC isoform expression. The results of these analyses are plotted in $\boldsymbol{A}-\boldsymbol{C}$. $\boldsymbol{A}$, There was a significant effect of self-administration and reinstatement on pPKC $\alpha /$ PKC $\alpha$ in cocaine/cocaine and saline/ cocaine-treated rats when compared with cocaine/saline and saline/saline-treated controls (Bonferroni's correction, ${ }^{*} p<0.05$ ). $\boldsymbol{B}$, There were no significant differences among treatments in terms of pPKC $\beta\|/ P K C ~ \beta\|$ expression in the accumbens shell. $C$, There was a significant increase in pPKC $\gamma / P K C ~ \gamma$ expression in the accumbens shell of the cocaine/cocaine group compared with the saline/saline, saline/cocaine, and cocaine/saline treatment groups (Bonferroni's correction, ${ }^{*} p<0.05$ ). There were $5-7$ rats per treatment.

3B. Active lever responses were analyzed with a one-way ANOVA, which revealed a significant main effect of treatment $\left(F_{(2,33)}=16.13\right.$, $p<0.0001)$. Post hoc analyses revealed significant differences in responding on the active lever between animals pretreated with vehicle or $3.0 \mu \mathrm{M}$ chelerythrine chloride and animals pretreated with 30.0 $\mu \mathrm{M}$ chelerythrine chloride (Tukey's HSD, $p<0.05$ ). No significant differences in inactive lever responding were found between treatments $\left(F_{(2,33)}=2.87, p<0.07\right)$.

The reinstatement of cocaine seeking was associated with increased phosphorylated PKC $\gamma$ in the nucleus accumbens shell

In these experiments, after an average of $\sim 7 \mathrm{~d}$ of extinction, rats with a previous history of cocaine self-administration or yoked saline controls were administered $10 \mathrm{mg} / \mathrm{kg}$ cocaine or saline (i.p.) and were allowed to self-administer saline under extinction conditions for $30 \mathrm{~min}$, at which point they were killed and their brains removed for the Western blot analyses. As expected, animals with a history of cocaine self-administration showed robust reinstatement of cocaine seeking, whereas the yoked saline controls did not (data not shown). The fluorescent densitometry results from the Western blots are shown in Figure 4. Unpaired $t$ tests indicated that there was no significant difference in expression of GAPDH between the saline and cocaine groups in the accumbens shell (data not shown). Ratios of phosphorylated to native PKC $\alpha$ (Fig. $4 A$ ), PKC $\beta$ II (Fig. $4 B$ ), and PKC $\gamma$ (Fig. $4 C$ ) were calculated and analyzed with two-way mixed factors ANOVAs, with factors of self-administration (saline or cocaine) and reinstatement challenge (saline or cocaine). Analysis of $\mathrm{pPKC} \alpha / \mathrm{PKC} \alpha$ data (Fig. $4 A$ ) revealed a significant main effect 


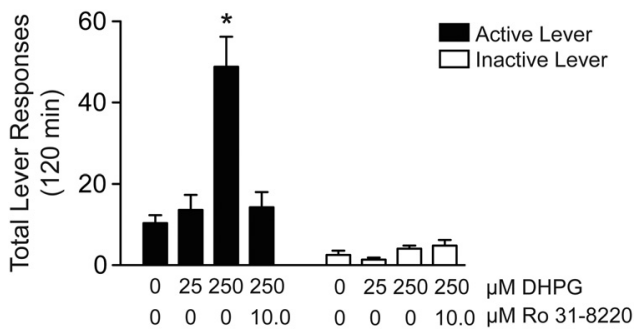

Figure 5. Microinjection of the $\mathrm{mGluR} 1 / 5$ agonist $D H P G$ into the accumbens shell reinstates cocaine seeking and is mediated, in part, by activation of PKC. Total number of responses (mean \pm SEM) on the active and inactive levers during the reinstatement test session following intra-accumbens shell administration of vehicle $(n=11), 25.0 \mu \mathrm{M}$ DHPG $(n=10), 250 \mu \mathrm{m}$ DHPG $(n=11)$, or $10.0 \mu \mathrm{m}$ Ro 31-8220 $+250 \mu \mathrm{M}$ DHPG $(n=11)$. There was a significant increase in active lever responding in animals treated with $250 \mu \mathrm{M} \mathrm{DHPG}$ when compared with animals treated with vehicle, $25.0 \mu \mathrm{M} \mathrm{DHPG}$, or 10.0 $\mu \mathrm{m}$ Ro 31-8220 + $250 \mu \mathrm{m} \mathrm{DHPG} \mathrm{(Tukey's}$ $\left.\mathrm{HSD}^{*}{ }^{*} p<0.05\right)$. No significant differences in responding on the inactive lever were found between treatments.

of self-administration $\left(F_{(1,18)}=22.0, p<0.001\right)$ and reinstatement $\left(F_{(1,18)}=94.0, p<0.001\right)$ as well as a strong trend toward a significant self-administration $\times$ reinstatement interaction $\left(F_{(1,18)}=3.9, p=0.058\right)$. Subsequent pairwise comparisons showed that there was a significant difference between the saline/cocaine $(n=7)$ and cocaine/cocaine $(n=5)$ groups and both the saline/saline $(n=5)$ and cocaine/saline $(n=5)$ groups (Bonferroni, $p<0.05)$. No significant effects of selfadministration $\left(F_{(1,20)}=1.1, p<0.30\right)$ or reinstatement $\left(F_{(1,20)}=4.0, p<0.06\right)$ on $\mathrm{pPKC} \beta \mathrm{II} / \mathrm{PKC} \beta \mathrm{II}$ expression were observed between treatments (Fig. $4 B$ ). Analysis of pPKC $\gamma / \mathrm{PKC} \gamma$ expression data (Fig. 4C) revealed a significant main effect of reinstatement $\left(F_{(1,20)}=18.0, p<0.001\right)$ as well as a significant self-administration $\times$ reinstatement interaction $\left(F_{(1,20)}=4.7\right.$, $p<0.04)$. Subsequent pairwise analyses showed that there was a significant difference between the cocaine/cocaine group $(n=7)$ and the saline/saline $(n=5)$, saline/cocaine $(n=7)$, and cocaine/ saline $(n=5)$ groups (Bonferroni, $p<0.05)$.

The role of novel $(\delta, \varepsilon, \eta$, and $\theta$ ) and atypical (protein kinase $\mathrm{M} \zeta$ and $\iota / \lambda) \mathrm{PKC}$ isoforms in cocaine seeking is unknown. PKC $\varepsilon$ is expressed in the nucleus accumbens (Saito et al., 1993) and emerging evidence suggests that this isoform may play a critical role in drug taking (Olive and Messing, 2004; Olive and Newton, 2010). While the present study examined conventional PKC isoforms only, it is possible that novel and/or atypical PKC isoforms may also play a critical role in the reinstatement of cocaine seeking.

\section{Intra-accumbens shell administration of the mGluR1/5} agonist DHPG promotes cocaine seeking, an effect blocked by pretreating the shell with the PKC inhibitor Ro 31-8220

Total lever responses (mean \pm SEM) following intra-accumbens shell administration of DHPG are shown in Figure 5. Active lever response were analyzed with a one-way ANOVA, which revealed a significant main effect of treatment $\left(F_{(3,39)}=15.11, p<\right.$ $0.0001)$. Post hoc analyses showed a significant difference between $250 \mu \mathrm{M}$ DHPG $(n=11)$ and vehicle $(n=11), 25.0 \mu \mathrm{M}$ DHPG $(n=10)$, and $250 \mu \mathrm{M}$ DHPG $+10.0 \mu \mathrm{M}$ Ro 31-8220 $(n=11)$ treatments. No significant differences on inactive lever responding were found between treatments $\left(F_{(3,39)}=2.33, p<0.09\right)$.

Administration of the PICK1 inhibitor FSC-231 directly into the accumbens shell attenuated cocaine seeking

Total active and inactive lever responses (mean \pm SEM) following a systemic priming injection of cocaine $(10 \mathrm{mg} / \mathrm{kg}$, i.p. $)$ in

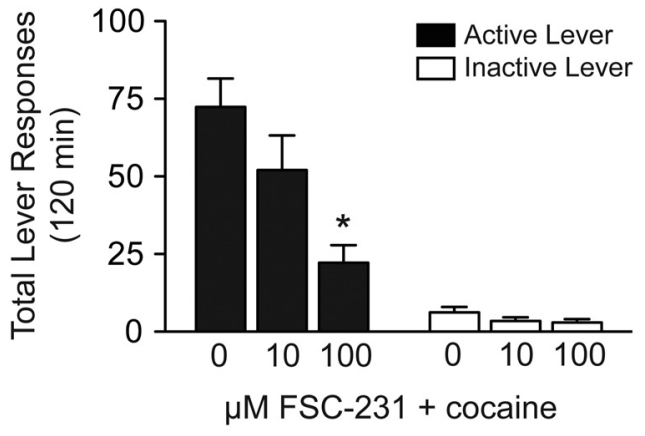

Figure 6. Administration of the PICK1 small-molecule inhibitor FSC-231 into the accumbens shell dose-dependently attenuates cocaine priming-induced reinstatement of drug seeking. Rats were administered vehicle $(n=15), 10.0(n=14)$ or $100(n=14) \mu \mathrm{M}$ FSC-231 into the accumbens shell $10 \mathrm{~min}$ before a priming injection of cocaine $(10 \mathrm{mg} / \mathrm{kg}$, i.p.). Total active and inactive lever responses (mean $\pm \mathrm{SEM}$ ) for the reinstatement test sessions are plotted. Active

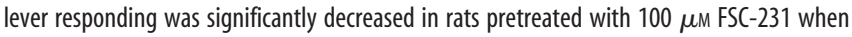
compared with vehicle-treated controls (Tukey's HSD, * $p<0.05$ ). No significant effects of treatment on inactive lever responding were observed.

animals pretreated with microinfusions of FSC-231 (vehicle, 10.0 or $100.0 \mu \mathrm{M}$ ) into the accumbens shell are shown in Figure 6. These data were analyzed with one-way ANOVAs, which did reveal a significant main effect of treatment on responses made on the active lever $\left(F_{(2,40)}=7.97, p<0.01\right)$. Subsequent pairwise analyses showed a significant difference between animals pretreated with $100.0 \mu \mathrm{M}$ FSC-231 $(n=14)$ and vehicle-treated controls $(n=15$; Tukey's HSD, $p<0.05)$. No significant differences in responses made on the inactive lever were found between treatments $\left(F_{(2,40)}=1.48, p<0.24\right)$. Microinjection sites for all behavioral experiments are shown in Figure 7.

Intra-accumbens shell administration of MPEP, YM 298198, Ro 31-8220, chelerythrine chloride, U73122, and FSC-231 had no effect on the reinstatement of sucrose seeking

When using receptor antagonists that decrease reinstatement of cocaine-seeking behavior, general drug-induced behavioral suppression is a concern. In the present experiments, two measures were used to evaluate potential nonspecific rate suppressing effects of intracranial drug administration. First, each operant chamber was equipped with an inactive lever, responses on which are often used as a measure of nonspecific alterations in lever responding. While intra-accumbens shell administration of MPEP, Ro 31-8220, chelerythrine chloride, U73122, and FSC231 had no significant effect on inactive lever responding, one could argue that responses were uniformly too low to meaningfully assess potential rate-suppressant effects of drug treatment. Therefore, we also assessed the ability of intra-accumbens shell microinjections of these compounds to alter sucrose reinstatement, where noncontingent administration of sucrose reinstates responding previously maintained by sucrose reinforcement. The effects of intra-accumbens shell YM 298198 were also tested because the role of accumbens mGluR1s in sucrose reinstatement is not known. Animals were administered 9.0 $\mu \mathrm{M} \operatorname{MPEP}(n=5)$, $50.0 \mu \mathrm{M}$ YM $298198(n=7), 40.0 \mu \mathrm{M} \mathrm{U} 73122(n=14), 10.0 \mu \mathrm{M}$ Ro 31-8220 $(n=11), 30.0 \mu \mathrm{M}$ chelerythrine chloride $(n=10)$, $100.0 \mu \mathrm{M}$ FSC-231 $(n=8)$, or their respective vehicles $(n=5$ each for MPEP and YM 298198; $n=14$ for U73122; $n=11$ for Ro $31-8220 ; n=10$ for chelerythrine chloride; $n=8$ for FSC-231) directly into the shell before sucrose reinstatement test sessions. Total active lever responses (mean \pm SEM) completed following intracranial infusions are listed in Table 1. Data analyses revealed 
no significant differences between treatments (unpaired $t$ tests, MPEP: $t_{(8)}=$ 0.30, $p<0.77$; YM 298198: $t_{(12)}=0.60$, $p<0.56$; U73122: $t_{(26)}=0.29, p<0.78$; Ro 31-8220: $t_{(20)}=0.30, p<0.77$; chelerythrine chloride: $t_{(18)}=0.70, p<0.49$; FSC-231: $\left.t_{(14)}=0.31, p=0.76\right)$. Together, these data suggest that attenuation of cocaine seeking following administration of MPEP, U73122, Ro 31-8220, chelerythrine chloride, and FSC-231 into the accumbens shell is not due to drug-induced motor impairments and that stimulation of accumbens shell mGluR1s does not play a role in sucrose-seeking behavior.

Previous studies demonstrated that systemic (Achat-Mendes et al., 2012) and intra-accumbens (Xie et al., 2012) administration of a selective mGluR1 antagonist does not affect food self-administration. Consistent with these results, intraaccumbens shell administration of a selective mGluR1 antagonist did not affect sucrose reinstatement in the present study. Systemic (Paterson et al., 2003; Bespalov et al., 2005; Gass et al., 2009) (but see, Paterson and Markou, 2005) and intra-accumbens shell (D’Souza and Markou, 2011) administration of a selective mGluR5 antagonist also has no effect on sucrose selfadministration. The role of mGluR5s in the reinstatement of sucrose seeking, however, is mixed as different mGluR5 antagonists have differential effects of sucrose seeking when administered systemically (Kumaresan et al., 2009; Watterson et al., 2013). The present results, however, indicate that intra-shell administration of an mGluR5 antagonist did not affect sucrose seeking. While mGluR1s and mGluR5s do not appear to play a generalized role in reinforced behaviors, future studies are needed to clarify the role of mGluR $5 \mathrm{~s}$ in the reinstatement of sucrose-seeking behavior.

\section{Discussion}

The present results indicate that (1) administration of a mGluR5, but not mGluR1, antagonist into the nucleus accumbens shell attenuates cocaine priming-induced reinstatement of drug seeking; (2) pharmacological inhibition of PLC or PKC in the shell attenuates cocaine seeking; (3) reinstatement of cocaine-seeking behavior is associated with increased activation of PKC $\gamma$ in the accumbens shell; (4) intra-accumbens shell mGluR1/5 agonist-induced reinstatement of cocaine seeking is attenuated following pharmacological inhibition of PKC in the shell; and (5) inhibition of PICK1 in the shell attenuates cocaine seeking. Collectively, these data suggest that stimulation of mGluR5 in the shell promotes cocaine seeking, in part, through activation of PLC and PKC $\gamma$, which, in turn, may activate PICK1 to influence the trafficking of GluA2-containing AMPA receptors.

\section{Role of nucleus accumbens type I mGluRs in cocaine seeking} The present findings contribute to and expand upon previous studies demonstrating a role for accumbens type I mGluR signaling in cocaine seeking. Administration of a selective mGluR1 antagonist directly into the core, but not shell, attenuates cocaine seeking (Xie et al., 2012). In contrast, systemic administration of a selective mGluR5 antagonist attenuates cocaine seeking (Iso et
Table 1. The reinstatement of sucrose seeking is not affected by intra-accumbens shell administration of an mGluR1 antagonist, PLC inhibitor, PKC inhibitors, or PICK1 inhibitor

\begin{tabular}{|c|c|c|c|}
\hline \multirow[b]{2}{*}{$\underline{\text { Treatment }}$} & \multicolumn{2}{|c|}{$\begin{array}{l}\text { Total active lever responses } \\
\text { (mean } \pm \text { SEM) }\end{array}$} & \multirow[b]{2}{*}{$t$ test $t_{(\mathrm{df})} ; p$} \\
\hline & Vehicle & Drug & \\
\hline $9.0 \mu \mathrm{M}$ MPEP & $142.4 \pm 19.96$ & $124.8 \pm 16.95$ & $t_{(8)}=0.30 ; p=0.77$ \\
\hline $50.0 \mu \mathrm{M} \mathrm{YM} 298198$ & $163.1 \pm 24.23$ & $110.3 \pm 8.89$ & $t_{(12)}=0.60 ; p=0.56$ \\
\hline $10.0 \mu \mathrm{m}$ Ro 31-8220 & $102.7 \pm 18.00$ & $109.7 \pm 15.13$ & $t_{(20)}=0.30 ; p=0.77$ \\
\hline $30.0 \mu \mathrm{m}$ Chelerythrine Cl & $102.7 \pm 18.00$ & $87.40 \pm 12.15$ & $t_{(18)}=0.70 ; p=0.49$ \\
\hline $40.0 \mu \mathrm{m}$ U73122 & $88.07 \pm 11.22$ & $83.50 \pm 11.42$ & $t_{(26)}=0.29 ; p=0.78$ \\
\hline $100 \mu \mathrm{M}$ FSC-231 & $107.9 \pm 18.74$ & $99.88 \pm 18.01$ & $t_{(14)}=0.31 ; p=0.76$ \\
\hline
\end{tabular}

No significant differences in active lever responding were noted between drug treatments and their respective vehicle treatments during sucrose reinstatement tests (unpaired $t$ test).

al., 2006; Kumaresan et al., 2009; Moussawi et al., 2009), an effect that is mediated by mGluR5s expressed in the shell (Kumaresan et al., 2009) and possibly the core, although these results are mixed (Bäckström and Hyytiä, 2007; Wang et al., 2013). The present data demonstrate that pharmacological inhibition of mGluR5s, but not mGluR1s, in the shell attenuates cocaine seeking. Consistent with these results, administration DHPG into the shell reinstated cocaine seeking. Stimulation of type I mGluRs also leads to activation of PLC (Conn and Pin, 1997). Here, we demonstrate that intra-shell administration of a PLC inhibitor attenuates cocaine seeking. Collectively, these findings clearly indicate that mGluR5s, but not mGluR1s, and PLC in the shell play a critical role in cocaine priming-induced reinstatement of drug seeking.

Type I mGluRs appear to play distinct roles in cocaine seeking depending on the mode of cocaine exposure (i.e., short-access vs long-access) and duration of withdrawal (i.e., short/extinction vs protracted/forced abstinence). For example, mGluR5-mediated signaling in the shell (present study) and core (Wang et al., 2013) 
plays a critical role in cocaine priming-induced reinstatement of drug seeking. Stimulation of mGluR5-PKC signaling may facilitate cocaine seeking by increasing synaptic expression of GluA1containing AMPA receptors (Anderson et al., 2008) and/or endocytosis of GluA2-containing receptors (Famous et al., 2008) in rats whose short-access self-administration behavior has been extinguished in $\sim 7 \mathrm{~d}$. In contrast, a growing body of evidence clearly indicates that stimulation of mGluR1-PKC signaling in the core promotes internalization of GluA1-containing AMPA receptors and increased synaptic expression of GluA2-containing AMPA receptors following protracted withdrawal from extendedaccess cocaine self-administration (McCutcheon et al., 2011; Loweth et al., 2013). Thus, with short-access paradigms, mGluR5 predominates during cocaine seeking while mGluR1 plays a critical role in cocaine seeking with extended-access paradigms.

\section{Role of conventional PKC isoforms in cocaine seeking}

Pharmacological inhibition of PKC regulates psychostimulantinduced behavioral plasticity (Olive and Messing, 2004; Lee and Messing, 2008; Olive and Newton, 2010). While currently available pharmacological inhibitors of PKC are nonspecific in that they do not differentiate between PKC isoforms, there is emerging evidence that accumbens PKC plays a critical role in cocaine-mediated behaviors (Cervo et al., 1997; Pierce et al., 1998). Our results demonstrate for the first time that administration of PKC inhibitors into the accumbens shell attenuated cocaine priming-induced reinstatement of drug seeking. The downstream targets that mediate the effects of PKC on cocaine seeking are not known but may include AMPA receptors (Famous et al., 2008).

Repeated exposure to psychostimulants can alter the expression of PKC isoforms in the brain (Olive and Messing, 2004; Lee and Messing, 2008; Olive and Newton, 2010). Here, we show that cocaine seeking is associated with increased activation of PKC $\gamma$, but not PKC $\alpha$ or PKC $\beta$ II, in the accumbens shell. Administration of noncontingent cocaine to naive and cocaine-experienced rats increased activation of $\mathrm{PKC} \alpha$, which suggests that these effects are not due to a history of cocaine taking. Previous studies have demonstrated that repeated cocaine administration increases the phosphorylation of some, but not all, isoforms of PKC in the accumbens and that these effects are brain region-specific (Steketee et al., 1998; Chen et al., 2007). For example, repeated experimenter-delivered cocaine is associated with increased $\mathrm{PKC} \beta \mathrm{I}$ expression only in the medial prefrontal cortex and no change in the expression of any PKC isoforms in the accumbens (Steketee et al., 1998). Furthermore, PKC $\gamma$ mRNA expression is increased in the accumbens following $5 \mathrm{~d}$ of withdrawal from self-administered cocaine (Thomas and Everitt, 2001). Collectively, these studies indicate that dissimilar experimental paradigms (i.e., experimenter-delivered vs self-administered infusions, withdrawal vs extinction, cocaine dose, etc.) may differentially influence expression of PKC isoforms in the brain. While it is possible that PKC activity could sensitize to repeated cocaine exposure in the absence of operant responding, the current results indicate that cocaine selfadministration/extinction is associated with the selective activation of PKC $\gamma$ in the shell.

\section{mGluR5, PKC, AMPA receptor trafficking and cocaine seeking}

Stimulation of type I mGluRs in the accumbens shell was sufficient to reinstate cocaine seeking. This effect is likely mediated by mGluR5s, and not mGluR1s, since intra-shell administration of an mGluR5, but not mGluR1, antagonist attenuated cocainepriming induced reinstatement of drug seeking (present study) (Kumaresan et al., 2009). These results are consistent with a recent study demonstrating reinstatement of cocaine seeking following infusion of an mGluR5 agonist into the accumbens core (Wang et al., 2013). Pharmacological inhibition of PKC in the shell was sufficient to attenuate intra-shell DHPG-induced reinstatement of drug seeking, indicating that stimulation of accumbens shell type I mGluRs activates PKC to promote cocaine seeking. DHPG has been shown to selectively increase phosphorylation of $\mathrm{PKC} \gamma$, but not $\mathrm{PKC} \alpha$ or $\mathrm{PKC} \beta \mathrm{I} / \mathrm{II}$ isoforms, which is consistent with the present findings demonstrating that cocaine reinstatement is associated with increased activation of PKC $\gamma$ in the shell (Sánchez-Pérez and Felipo, 2005; Takagi et al., 2010). Together, these findings indicate that mGluR5-induced activation of PLC and PKC $\gamma$ plays a critical role in promoting cocaine seeking.

An emerging literature indicates that AMPA receptor trafficking plays a prominent role in cocaine seeking (Schmidt and Pierce, 2010; Pierce and Wolf, 2013). Following a 45 d withdrawal period after $10 \mathrm{~d}$ of extended-access cocaine self-administration, there was increased cell surface expression of GluA1 and GluA3, but not GluA2, in the accumbens (Conrad et al., 2008). Moreover, cocaine priming-induced reinstatement of drug seeking is associated with increased surface expression of GluA1containing AMPA receptors in the accumbens shell (Anderson et al., 2008). PKC phosphorylates GluA1 at Ser831, which facilitates GluA1 insertion into the plasma membrane (Song and Huganir, 2002; Lin et al., 2009). Therefore, it is possible that stimulation of mGluR5-PLC-PKC signaling in the shell promotes cocaine seeking, in part, by promoting the transport of GluA1-containing AMPA receptors to synapses.

Cocaine reinstatement is also associated with increased phosphorylation of accumbens GluA2 at Ser880, a PKC phosphorylation site (Famous et al., 2008; Wiggins et al., 2011). PKC-induced phosphorylation of GluA2 at Ser880 and the subsequent association of GluA2 with PICK1 results in rapid internalization of GluA2containing AMPA receptors (Chung et al., 2000; Perez et al., 2001; Collingridge et al., 2004; Terashima et al., 2004) (Liu and CullCandy, 2005; but see, Gardner et al., 2005). PKC $\alpha$ (Perez et al., 2001) and PKC $\gamma$ (Patten and Ali, 2009), the same PKC isoforms identified in the present study to play a role in cocaine seeking, phosphorylate GluA2 at Ser880 and together with PICK1 promote internalization of GluA2 subunits. Our results indicate that administration of a PICK1 inhibitor into the shell attenuates cocaine seeking and imply that cocaine reinstatement is associated with endocytosis of GluA2containing AMPA receptors. This hypothesis is consistent with a recent study demonstrating that disruption of PICK1-GluA2 interactions in the accumbens is sufficient to attenuate cocaine seeking (Famous et al., 2008). The present results suggest that stimulation of mGluR5-PLC-PKC signaling in the shell regulates cocaine seeking by promoting internalization of GluA2-containing AMPA receptors. This hypothesis is supported by a recent study demonstrating that DHPG-induced phosphorylation of GluA2 in the striatum is blocked by a PKC inhibitor (Ahn and Choe, 2010). Future studies are required to determine whether cocaine seeking is associated with mGluR5-mediated trafficking of GluA1 and/or GluA2 AMPA receptor subunits in the accumbens.

\section{Conclusions}

The present results indicate that stimulation of mGluR5s, but not mGluR1s, in the accumbens shell activates PKC to promote cocaine seeking. During the reinstatement of cocaine seeking, in- 
creased phosphorylation of PKC $\gamma$ was observed in the shell, which may promote removal of GluA2-containing AMPA receptors from synapses (Pierce and Wolf, 2013). Consistent with these results, pharmacological inhibition of PICK1 attenuated cocaine priming-induced reinstatement of drug seeking. Combined with results showing increased GluA1 surface expression during the reinstatement of cocaine seeking (Anderson et al., 2008), these findings suggest that activation of mGluR5-PLC-PKC signaling in the shell may produce a dynamic, rapid exchange between a GluA1-containing population of AMPA receptors and a GluA2containing population of AMPA receptors, which promotes cocaine priming-induced reinstatement of drug seeking.

\section{References}

Achat-Mendes C, Platt DM, Spealman RD (2012) Antagonism of metabotropic glutamate 1 receptors attenuates behavioral effects of cocaine and methamphetamine in squirrel monkeys. J Pharmacol Exp Ther 343:214-224. CrossRef Medline

Ahn SM, Choe ES (2010) Alterations in GluR2 AMPA receptor phosphorylation at serine 880 following group I metabotropic glutamate receptor stimulation in the rat dorsal striatum. J Neurosci Res 88:992-999. Medline

Anderson SM, Bari AA, Pierce RC (2003) Administration of the D1-like dopamine receptor antagonist $\mathrm{SCH}-23390$ into the medial nucleus accumbens shell attenuates cocaine priming-induced reinstatement of drug-seeking behavior in rats. Psychopharmacology 168:132-138. CrossRef Medline

Anderson SM, Famous KR, Sadri-Vakili G, Kumaresan V, Schmidt HD, Bass CE, Terwilliger EF, Cha JH, Pierce RC (2008) CaMKII: a biochemical bridge linking accumbens dopamine and glutamate systems in cocaine seeking. Nat Neurosci 11:344-353. CrossRef Medline

Aujla H, Beninger RJ (2003) Intra-accumbens protein kinase C inhibitor NPC 15437 blocks amphetamine-produced conditioned place preference in rats. Behav Brain Res 147:41-48. CrossRef Medline

Bäckström P, Hyytiä P (2006) Ionotropic and metabotropic glutamate receptor antagonism attenuates cue-induced cocaine seeking. Neuropsychopharmacology 31:778-786. CrossRef Medline

Bäckström P, Hyytiä P (2007) Involvement of AMPA/kainate, NMDA, and mGlu5 receptors in the nucleus accumbens core in cue-induced reinstatement of cocaine seeking in rats. Psychopharmacology 192:571-580. CrossRef Medline

Bespalov AY, Dravolina OA, Sukhanov I, Zakharova E, Blokhina E, Zvartau E, Danysz W, van Heeke G, Markou A (2005) Metabotropic glutamate receptor (mGluR5) antagonist MPEP attenuated cue- and scheduleinduced reinstatement of nicotine self-administration behavior in rats. Neuropharmacology 49:167-178. CrossRef Medline

Cervo L, Mukherjee S, Bertaglia A, Samanin R (1997) Protein kinases A and $\mathrm{C}$ are involved in the mechanisms underlying consolidation of cocaine place conditioning. Brain Res 775:30-36. CrossRef Medline

Chen Q, Lee TH, Wetsel WC, Sun QA, Liu Y, Davidson C, Xiong X, Ellinwood EH, Zhang X (2007) Reversal of cocaine sensitization-induced behavioral sensitization normalizes GAD67 and GABAA receptor alpha2 subunit expression, and PKC zeta activity. Biochem Biophys Res Commun 356:733-738. CrossRef Medline

Chiamulera C, Epping-Jordan MP, Zocchi A, Marcon C, Cottiny C, Tacconi S, Corsi M, Orzi F, Conquet F (2001) Reinforcing and locomotor stimulant effects of cocaine are absent in mGluR5 null mutant mice. Nat Neurosci 4:873-874. CrossRef Medline

Chung HJ, Xia J, Scannevin RH, Zhang X, Huganir RL (2000) Phosphorylation of the AMPA receptor subunit GluR2 differentially regulates its interaction with PDZ domain-containing proteins. J Neurosci 20:72587267. Medline

Collingridge GL, Isaac JT, Wang YT (2004) Receptor trafficking and synaptic plasticity. Nat Rev Neurosci 5:952-962. CrossRef Medline

Conn PJ, Pin JP (1997) Pharmacology and functions of metabotropic glutamate receptors. Annu Rev Pharmacol Toxicol 37:205-237. CrossRef Medline

Conrad KL, Tseng KY, Uejima JL, Reimers JM, Heng LJ, Shaham Y, Marinelli M, Wolf ME (2008) Formation of accumbens GluR2-lacking AMPA receptors mediates incubation of cocaine craving. Nature 454:118-121. CrossRef Medline
D’Souza MS, Markou A (2011) Metabotropic glutamate receptor 5 antagonist 2-methyl-6-(phenylethynyl)pyridine (MPEP) microinfusions into the nucleus accumbens shell or ventral tegmental area attenuate the reinforcing effects of nicotine in rats. Neuropharmacology 61:1399-1405. CrossRef Medline

Famous KR, Kumaresan V, Sadri-Vakili G, Schmidt HD, Mierke DF, Cha JH, Pierce RC (2008) Phosphorylation-dependent trafficking of GluR2containing AMPA receptors in the nucleus accumbens plays a critical role in the reinstatement of cocaine seeking. J Neurosci 28:11061-11070. CrossRef Medline

Frye CA, Walf AA (2008) In the ventral tegmental area, progestogens' membrane-mediated actions for lordosis of rats involve the secondmessenger phospholipase C. Brain Res 1230:218-223. CrossRef Medline

Gardner SM, Takamiya K, Xia J, Suh JG, Johnson R, Yu S, Huganir RL (2005) Calcium-permeable AMPA receptor plasticity is mediated by subunitspecific interactions with PICK1 and NSF. Neuron 45:903-915. CrossRef Medline

Gass JT, Osborne MP, Watson NL, Brown JL, Olive MF (2009) mGluR5 antagonism attenuates methamphetamine reinforcement and prevents reinstatement of methamphetamine-seeking behavior in rats. Neuropsychopharmacology 34:820-833. CrossRef Medline

Iso Y, Grajkowska E, Wroblewski JT, Davis J, Goeders NE, Johnson KM, Sanker S, Roth BL, Tueckmantel W, Kozikowski AP (2006) Synthesis and structure-activity relationships of 3-[(2-methyl-1,3-thiazol-4yl)ethynyl]pyridine analogues as potent, noncompetitive metabotropic glutamate receptor subtype 5 antagonists; search for cocaine medications. J Med Chem 49:1080-1100. CrossRef Medline

Kenny PJ, Paterson NE, Boutrel B, Semenova S, Harrison AA, Gasparini F, Koob GF, Skoubis PD, Markou A (2003) Metabotropic glutamate 5 receptor antagonist MPEP decreased nicotine and cocaine selfadministration but not nicotine and cocaine-induced facilitation of brain reward function in rats. Ann NY Acad Sci 1003:415-418. CrossRef Medline

Kenny PJ, Boutrel B, Gasparini F, Koob GF, Markou A (2005) Metabotropic glutamate 5 receptor blockade may attenuate cocaine self-administration by decreasing brain reward function in rats. Psychopharmacology 179: 247-254. CrossRef Medline

Kumaresan V, Yuan M, Yee J, Famous KR, Anderson SM, Schmidt HD, Pierce RC (2009) Metabotropic glutamate receptor 5 (mGluR5) antagonists attenuate cocaine priming- and cue-induced reinstatement of cocaine seeking. Behav Brain Res 202:238-244. CrossRef Medline

Lee AM, Messing RO (2008) Protein kinases and addiction. Ann NY Acad Sci 1141:22-57. CrossRef Medline

Lee B, Platt DM, Rowlett JK, Adewale AS, Spealman RD (2005) Attenuation of behavioral effects of cocaine by the metabotropic glutamate receptor 5 antagonist 2-methyl-6-(phenylethynyl)-pyridine in squirrel monkeys: comparison with dizocilpine. J Pharmacol Exp Ther 312:1232-1240. Medline

Li YQ, Xue YX, He YY, Li FQ, Xue LF, Xu CM, Sacktor TC, Shaham Y, Lu L (2011) Inhibition of PKMzeta in nucleus accumbens core abolishes longterm drug reward memory. J Neurosci 31:5436-5446. CrossRef Medline

Lin DT, Makino Y, Sharma K, Hayashi T, Neve R, Takamiya K, Huganir RL (2009) Regulation of AMPA receptor extrasynaptic insertion by $4.1 \mathrm{~N}$, phosphorylation and palmitoylation. Nat Neurosci 12:879-887. CrossRef Medline

Liu SJ, Cull-Candy SG (2005) Subunit interaction with PICK and GRIP controls $\mathrm{Ca}^{2+}$ permeability of AMPARs at cerebellar synapses. Nat Neurosci 8:768-775. CrossRef Medline

Loweth JA, Svoboda R, Austin JD, Guillory AM, Vezina P (2009) The PKC inhibitor Ro31-8220 blocks acute amphetamine-induced dopamine overflow in the nucleus accumbens. Neurosci Lett 455:88-92. CrossRef Medline

Loweth JA, Tseng KY, Wolf ME (2013) Adaptations in AMPA receptor transmission in the nucleus accumbens contributing to incubation of cocaine craving. Neuropharmacology. Advance online publication. doi:0.1016/j.neuropharm.2013.04.061. CrossRef

McCutcheon JE, Loweth JA, Ford KA, Marinelli M, Wolf ME, Tseng KY (2011) Group I mGluR activation reverses cocaine-induced accumulation of calcium-permeable AMPA receptors in nucleus accumbens synapses via a protein kinase C-dependent mechanism. J Neurosci 31:14536-14541. CrossRef Medline

Moussawi K, Pacchioni A, Moran M, Olive MF, Gass JT, Lavin A, Kalivas PW 
(2009) N-Acetylcysteine reverses cocaine-induced metaplasticity. Nat Neurosci 12:182-189. CrossRef Medline

Muly EC, Maddox M, Smith Y (2003) Distribution of mGluRlalpha and mGluR5 immunolabeling in primate prefrontal cortex. J Comp Neurol 467:521-535. CrossRef Medline

Narita M, Akai H, Nagumo Y, Sunagawa N, Hasebe K, Nagase H, Kita T, Hara C, Suzuki T (2004) Implications of protein kinase C in the nucleus accumbens in the development of sensitization to methamphetamine in rats. Neuroscience 127:941-948. CrossRef Medline

Olive MF, Messing RO (2004) Protein kinase C isozymes and addiction. Mol Neurobiol 29:139-154. CrossRef Medline

Olive MF, Newton PM (2010) Protein kinase C isozymes as regulators of sensitivity to and self-administration of drugs of abuse-studies with genetically modified mice. Behav Pharmacol 21:493-499. CrossRef Medline

Olive MF, McGeehan AJ, Kinder JR, McMahon T, Hodge CW, Janak PH, Messing RO (2005) The mGluR5 antagonist 6-methyl-2-(phenylethynyl)pyridine decreases ethanol consumption via a protein kinase $\mathrm{C}$ epsilondependent mechanism. Mol Pharmacol 67:349-355. Medline

Park WK, Bari AA, Jey AR, Anderson SM, Spealman RD, Rowlett JK, Pierce RC (2002) Cocaine administered into the medial prefrontal cortex reinstates cocaine-seeking behavior by increasing AMPA receptor-mediated glutamate transmission in the nucleus accumbens. J Neurosci 22:2916-2925. Medline

Paterson NE, Markou A (2005) The metabotropic glutamate receptor 5 antagonist MPEP decreased break points for nicotine, cocaine and food in rats. Psychopharmacology 179:255-261. CrossRef Medline

Paterson NE, Semenova S, Gasparini F, Markou A (2003) The mGluR5 antagonist MPEP decreased nicotine self-administration in rats and mice. Psychopharmacology 167:257-264. Medline

Patten SA, Ali DW (2009) PKCgamma-induced trafficking of AMPA receptors in embryonic zebrafish depends on NSF and PICK1. Proc Natl Acad Sci U S A 106:6796-6801. CrossRef Medline

Paxinos G, Watson C (1997) The rat brain in stereotaxic coordinates. New York: Academic.

Perez JL, Khatri L, Chang C, Srivastava S, Osten P, Ziff EB (2001) PICK1 targets activated protein kinase Calpha to AMPA receptor clusters in spines of hippocampal neurons and reduces surface levels of the AMPAtype glutamate receptor subunit 2. J Neurosci 21:5417-5428. Medline

Pierce RC, Wolf ME (2013) Psychostimulant-induced neuroadaptations in nucleus accumbens AMPA receptor transmission. In: Addiction (Pierce RC, Kenny PJ, eds), pp 121-134. Cold Spring Harbor, New York: Cold Spring Harbor Laboratory.

Pierce RC, Quick EA, Reeder DC, Morgan ZR, Kalivas PW (1998) Calciummediated second messengers modulate the expression of behavioral sensitization to cocaine. J Pharmacol Exp Ther 286:1171-1176. Medline

Platt DM, Rowlett JK, Spealman RD (2008) Attenuation of cocaine selfadministration in squirrel monkeys following repeated administration of the mGluR5 antagonist MPEP: comparison with dizocilpine. Psychopharmacology 200:167-176. CrossRef Medline

Rouse ST, Marino MJ, Bradley SR, Awad H, Wittmann M, Conn PJ (2000) Distribution and roles of metabotropic glutamate receptors in the basal ganglia motor circuit: implications for treatment of Parkinson's disease and related disorders. Pharmacol Ther 88:427-435. CrossRef Medline

Saito N, Itouji A, Totani Y, Osawa I, Koide H, Fujisawa N, Ogita K, Tanaka C (1993) Cellular and intracellular localization of epsilon-subspecies of protein kinase $\mathrm{C}$ in the rat brain; presynaptic localization of the epsilonsubspecies. Brain Res 607:241-248. CrossRef Medline

Sánchez-Pérez AM, Felipo V (2005) Serines 890 and 896 of the NMDA receptor subunit NR1 are differentially phosphorylated by protein kinase C isoforms. Neurochem Int 47:84-91. CrossRef Medline

Schmidt HD, Pierce RC (2010) Cocaine-induced neuroadaptations in glutamate transmission: potential therapeutic targets for craving and addiction. Ann NY Acad Sci 1187:35-75. CrossRef Medline

Schwendt M, Sigmon SA, McGinty JF (2012) RGS4 overexpression in the rat dorsal striatum modulates mGluR5- and amphetamine-mediated behavior and signaling. Psychopharmacology 221:621-635. CrossRef Medline

Shigemoto R, Nomura S, Ohishi H, Sugihara H, Nakanishi S, Mizuno N
(1993) Immunohistochemical localization of a metabotropic glutamate receptor, mGluR5, in the rat brain. Neurosci Lett 163:53-57. CrossRef Medline

Song I, Huganir RL (2002) Regulation of AMPA receptors during synaptic plasticity. Trends Neurosci 25:578-588. CrossRef Medline

Steketee JD, Rowe LA, Chandler LJ (1998) The effects of acute and repeated cocaine injections on protein kinase $\mathrm{C}$ activity and isoform levels in dopaminergic brain regions. Neuropharmacology 37:339-347. CrossRef Medline

Swanson CJ, Baker DA, Carson D, Worley PF, Kalivas PW (2001) Repeated cocaine administration attenuates group I metabotropic glutamate receptor-mediated glutamate release and behavioral activation: a potential role for Homer. J Neurosci 21:9043-9052. Medline

Takagi N, Besshoh S, Morita H, Terao M, Takeo S, Tanonaka K (2010) Metabotropic glutamate mGlu5 receptor-mediated serine phosphorylation of NMDA receptor subunit NR1 in hippocampal CA1 region after transient global ischemia in rats. Eur J Pharmacol 644:96-100. CrossRef Medline

Terashima A, Cotton L, Dev KK, Meyer G, Zaman S, Duprat F, Henley JM, Collingridge GL, Isaac JT (2004) Regulation of synaptic strength and AMPA receptor subunit composition by PICK1. J Neurosci 24: 5381-5390. CrossRef Medline

Testa CM, Standaert DG, Landwehrmeyer GB, Penney JB Jr, Young AB (1995) Differential expression of mGluR5 metabotropic glutamate receptor mRNA by rat striatal neurons. J Comp Neurol 354:241-252. CrossRef Medline

Thomas KL, Everitt BJ (2001) Limbic-cortical-ventral striatal activation during retrieval of a discrete cocaine-associated stimulus: a cellular imaging study with gamma protein kinase C expression. J Neurosci 21:2526-2535. Medline

Thorsen TS, Madsen KL, Rebola N, Rathje M, Anggono V, Bach A, Moreira IS, Stuhr-Hansen N, Dyhring T, Peters D, Beuming T, Huganir R, Weinstein H, Mulle C, Strømgaard K, Rønn LC, Gether U (2010) Identification of a small-molecule inhibitor of the PICK1 PDZ domain that inhibits hippocampal LTP and LTD. Proc Natl Acad Sci U S A 107:413-418. CrossRef Medline

Timmer KM, Steketee JD (2012) Examination of a role for metabotropic glutamate receptor 5 in the medial prefrontal cortex in cocaine sensitization in rats. Psychopharmacology 221:91-100. CrossRef Medline

Titley HK, Heskin-Sweezie R, Broussard DM (2010) The bidirectionality of motor learning in the vestibulo-ocular reflex is a function of cerebellar mGluR1 receptors. J Neurophysiol 104:3657-3666. CrossRef Medline

Wang X, Moussawi K, Knackstedt L, Shen H, Kalivas PW (2013) Role of mGluR5 neurotransmission in reinstated cocaine-seeking. Addict Biol 18:40-49. CrossRef Medline

Watterson LR, Kufahl PR, Nemirovsky NE, Sewalia K, Hood LE, Olive MF (2013) Attenuation of reinstatement of methamphetamine-, sucrose-, and food-seeking behavior in rats by fenobam, a metabotropic glutamate receptor 5 negative allosteric modulator. Psychopharmacology 225:151-159. CrossRef Medline

Wiggins A, Smith RJ, Shen HW, Kalivas PW (2011) Integrins modulate relapse to cocaine-seeking. J Neurosci 31:16177-16184. CrossRef Medline

Wilkie MB, Besheer J, Kelley SP, Kumar S, O'Buckley TK, Morrow AL, Hodge CW (2007) Acute ethanol administration rapidly increases phosphorylation of conventional protein kinase $\mathrm{C}$ in specific mammalian brain regions in vivo. Alcohol Clin Exp Res 31:1259-1267. CrossRef Medline

Xie X, Lasseter HC, Ramirez DR, Ponds KL, Wells AM, Fuchs RA (2012) Subregion-specific role of glutamate receptors in the nucleus accumbens on drug context-induced reinstatement of cocaine-seeking behavior in rats. Addict Biol 17:287-299. CrossRef Medline

Yang SJ, Hwang JC (2007) Ca++ influx is essential for the hypotensive response to arginine vasopressin-induced neuron activation of the area postrema in the rat. Brain Res 1163:56-71. CrossRef Medline

Zhang HM, Lin N, Dong Y, Su Q, Luo M (2011) Effect of perinatal thyroid hormone deficiency on expression of rat hippocampal conventional protein kinase C isozymes. Mol Cell Biochem 353:65-71. CrossRef Medline 